\title{
Relationship Between Trade Openness and Energy Consumption in Oil Importing Asian Countries
}

\author{
Imtiaz Arif * $\quad$ Syeda Wajiha Kazmi ${ }^{\dagger} \quad$ Lubna Khan ${ }^{\ddagger}$
}

\begin{abstract}
The present study intended to examine the impact of trade on energy consumption using data of four oil importing, heavily populated, and developing economies of Asia namely Pakistan, India, China and Bangladesh. The study covers the period of 1972 to 2011. The data was checked for the Cross-sectional Dependency using CD-test, then CIPS panel unit root test, Panel cointegration, and Pooled Mean Group estimates approaches were used. Empirical results confirmed the Long-run relationship between energy consumption and trade openness. This study confirms the influence of trade on energy consumption and that they are positively related. International trade increases the energy demand and economic activities. However, high energy demand causes high energy price which negatively impacts on energy consumption and hence reduces the energy consumption. Therefore, there are many implications for the energy conservation and trade policy makers to consider in all four countries.
\end{abstract}

Keywords: Energy consumption, energy price, trade openness, gross domestic product, Asian developing countries.

\section{Introduction}

In the world of globalization, any good or service produced within a country is one way or other connected with the use of energy. However, industries are struggling for international trading as it is one of the components which impacts the industrial sector composition and energy usage of a country (Machado, Schaeffer, \& Worrell, 2011). The relationship between trade and energy consumption is considered as the most extensively researched areas in economics. Oil works as a source of energy that runs an economic structure and therefore, its continuous supply is necessary for the progress and development of any nation (Gupta, 2008). Furthermore, it is clear that oil and natural gas are the two highest sources that make up about $60 \%$ of the global energy demand around the world (Wasti, 2013). In Asian countries, the transportation and power sectors consume huge amount of petro-fuel as it is used in all vehicles to transport goods from one place to another. In the recent decade, technological advancement, population growth, and trade expansion have raised the energy demand. Around the global economy, trade, energy consumption, and economic activities

\footnotetext{
*Asst. Professor, IQRA University, Karachi. E-mail: arif.i@iuk.edu.pk

${ }^{\dagger}$ Research \& Communication Assistant, IQRA University, Karachi. E-mail: wajiha.kazmi@iuk.edu.pk

${ }^{\ddagger}$ Research Associate, IQRA University, Karachi. Email: lubna.khan@iuk.edu.pk
} 
tend to move together so it is important to study the relationship of energy consumption and trade openness.

Trade openness is an important factor for economic growth. Free flow of trade across borders raises the economic activities and energy demand (Sadorsky, 2012). It enables developing countries to import modern technologies which make the energy usage efficient and raises the national output. Furthermore, energy influences trade in different ways. It considers the core input in the production process and transportation because machinery and vehicles require energy/fuel. An insufficient amount of energy may inversely affect the trade. Therefore, higher energy consumption leads to trade expansion. More specifically, Asian countries cover one-quarter of the world's trade in goods. The Trade expansion in Asian countries has been growing fast since 1970. In 1980, the trade was approximately worth US 0.8 trillion dollars, but in 2011 it raised up to US 14 trillion dollars.

Researchers have started showing interest to study the influence of energy consumption after the unprecedented rise in the prices of oil started in the early 1970's. This rise in oil prices consequently rose the bills for the imported oil with a very wide margin. As a result, many steps were taken by those countries to save energy in order to lower down their dependency on oil imported from these oil exporting countries (Al-Iriani, 2006). The previous studies conducted in the Middle Eastern countries shed light on the relationship between trade and energy consumption and showed a positive relation of energy consumption with trade (Sadorsky, 2011; Narayan \& Smyth, 2009; Sadorsky, 2012). For the last three decades, many south Asian developing economies have seen major changes in terms of growth in energy consumption, trade, and income. This also brings up an interest in researchers to find the growth effects in trade and energy consumption (Sadorsky, 2011). The energy demand is increasing worldwide and is expected to frequently increase in 2030 by approx. 53\% (Khan \& Dessouky, 2009).

In Pakistan, the energy shortage is one of the challenges faced by the economy. Pakistan is one of the net importers of oil products. Since 1990's, the oil production has varied from 55,000 to 70,000 barrels per day (bbl/d) in Pakistan. However, the consumption of oil has increased and averaged from $418000 \mathrm{bbl} / \mathrm{d}$ in 2010 to 440,000 bbl/d in 2012 whereas, $62,000 \mathrm{bbl} / \mathrm{d}$ of oil was produced in 2012. On the other hand, the income earned through textile and woolen products' export showed a decrease of 25.3 and 5.1 percent respectively (Sadorsky, 2012). Bangladesh is also a net oil importer. In 2012, Bangladesh produced almost 6,000 barrels per day (bbl/d) while used almost 114,000 bbl/d. Furthermore, India was found to be the 3rd largest importer of petroleum and oil products in the world following China, United States, and Japan. India depends mostly on the Middle East for its crude oil imports. Similarly, China is one of the industrialized countries in Asia, which consumes huge quantities of energy and has higher degrees of economic growth, which is led by exports (Narayan \& Smyth, 2009). China is the fastest growing economy and its heavy population makes it the biggest energy consumer and producer.

There are numerous studies conducted on the causal relationship between energy consumption and growth (Payne, 2010; Ozturk, 2010; Yang, 2000). In addition, some other researchers studied the relationship of exports and national output (Lean \& Smyth, 2010a; Halicioglu, 2010). Despite a large number of studies on energy consumption, economic growth and trade in developed and developing countries, there is no such study conducted 
that investigates the effects of trade openness on energy consumption in four Asian oil importing economies. Consequently, this paper proposes to analyze the effects of trade openness on energy use in four Asian oil importing countries namely Pakistan, China, India and Bangladesh.

The remainder of the paper is structured as follows: Section 2 covers a brief review of empirical literature, Section 3 illustrates a model and a methodology, Section 4 discusses the empirical results and lastly, section 5 concludes the entire study and give policy implications and future recommendations.

\section{Literature Review}

Trade, energy consumption and output of a country are three variables that are found to be interlinked with each other over a wide period of time (Sadorsky, 2012). The relationship between energy consumption and trade is significant to study for many reasons; if there is a causal relationship found running from energy consumption to export and import, then the reduction in energy caused by the policies formed to conserve energy will also cause the level of export and import to go down. On the other hand, if there is a one-way causal relationship found running from export and import to energy consumption, then energy conservation policies will not harm the trade in the region (Sadorsky, 2011).

Kyophilavong, Shahbaz, Anwar, and Masood (2015) studied the long-run relationship between trade openness, energy consumption, and economic growth by using Bayer and Hanck cointegration approach. The results confirmed the cointegration among variables and also found that trade openness and energy consumption have a feedback effect, which will subsequently influence economic growth. Likewise Azam, Khan, Zaman, and Ahmad (2015) explored the factors that affect energy consumption. It is found that trade openness has a great influence on the energy consumption of the country. Whereas, economic growth, human development, and foreign direct inflow are also found important factors that affect energy consumption.

Shahzad, Kumar, Zakaria, and Hurr (2017) examined the long-run relationship between trade openness and energy consumption. The results of the Panel ARDL bound test indicated the long run relationship between trade and energy consumption. Nevertheless, this work also revealed that high energy consumption strengthens the financial growth of the nation. The work of Palamalai, Ravindra, and Prakasam (2015) highlighted the causal relationship of trade and energy consumption. Results showed the bi-directional relationship of both the variables. It also revealed that more energy consumption boosts economic activity. Similarly, Brini, Amara, and Jemmali (2017) determined the bi-directional relationship of international trade and energy consumption in the short run.

Furthermore, the exports made in one country need different machinery and vehicles to be transferred to other countries and these machineries require energy input to be operated. This means that an increase in export causes energy consumption to rise as well. There is also a possibility for a neutral relationship to exist between energy and exports, where the correlation between both variables is insignificant enough for it to predict significant relationship at conventional test levels (Sadorsky, 2012). 
The increase in imports of a country also causes the energy usage to increase as transportation is also required to move import goods around. Moreover, the imports of products like vehicles and appliances which require energy to operate causes the energy consumption to rise as well. Similarly, if there is a positive and direct relationship between energy consumption and trade (export and import), then increase in one will also cause the other to rise and the decrease in one will ultimately cause a decline in the other. This will have negative consequences for the growth of an economy due to the fact that the decrease in energy usage will cause the imports to decline (Sadorsky, 2012).

Narayan and Smyth (2009); Sadorsky (2011) studied the relationship of trade with energy consumption for Middle Eastern countries and found a positive significant relationship. Similarly, the findings of Lean and Smyth (2010b, 2010a) revealed a positive relationship between trade and energy consumption in South Asian countries. Narayan and Smyth (2009) investigated the relationship of causality among energy consumption, gross domestic product and exports for six Middle-East countries and found significant bi-directional relationship among the variables. In contrast to the studies done on the oil exporting countries, Hye and Riaz (2008) examined the direction of causality amid energy use and economic growth in Pakistan and found causality between the variables in the short-run. Similarly, Chaudhry, Safdar, and Farooq (2012) examined the relationship between energy consumption and economic growth for Pakistan and the results showed that the electricity usage supported economic growth along with other energy sources. Due to heavy imports, there was a negative impact of oil consumption on the growth of the economy however, trade openness showed a positive effect on economic growth. Furthermore, Shahbaz and Feridun (2012) explored a long-term relationship between consumption of electricity and economic growth and the results proved that the economic growth leads to electricity use in Pakistan but electricity usage does not lead to growth in the economy. Shahbaz and Lean (2012) re-explored the association between electricity consumption and economic growth in Pakistan and found positive impact of electricity usage on economic growth. Lau, Chye, and Choong (2011) re-examined the causal relationship between energy usage and gross-domestic product for selected Asian countries and the findings predicted equilibriums in the long-run whereas, causality was found to run from the energy use to the GDP in short-run. In a similar study on Asian oil importing countries, Li (2014) aimed to scrutinize the connection between export and new energy consumption in China and the results showed a feedback relation between China's export trade and new energy consumption. The exports contribute more to energy consumption than new energy consumption contributes to export trade.

Shiu and Lam (2004) investigated the relationship of causality between electricity use and real GDP for China. The real GDP and electricity consumption for China are cointegrated as the estimation results show unidirectional causality that runs from electricity use to real GDP. The researchers suggest that the government of China must reduce the barriers on electricity consumption to predict a rise in growth of real GDP. Similarly, Li (2010) examined the relation of energy use with export and findings revealed a two-way relationship between export and energy use.

On the basis of above empirical evidences, we noted that energy is an important source that affects trade and economic growth of the country. It is apparent from the existing 
literature that trade and energy consumption have a positive and causal relationship. Nevertheless, due to the shortage of energy supply, it also inversely affects the imports and exports of the country. By analyzing the above mentioned literature, we conclude that;

$H_{0}$ : Trade openness has a significant and positive effect on the energy consumption.

\section{Model Specification, Data and Methodology}

In this study, we aim to investigate the effects of trade openness on energy consumption in four oil importing nations. Therefore, we propose a simple energy consumption function along with some other variables, which are as follow:

$$
E C_{i t}=f\left(T O_{i t}, X\right)
$$

Where $E C_{i t}$ is the Total energy consumption for country, $\left(T O_{i t}\right)$ is the Trade openness (exports plus imports) and $\mathrm{X}$ is the set of control variables such as Gross Domestic Product $\left(G D P_{i t}\right)$ and Energy price $\left(E P_{i t}\right)$. The subscript $i$ is the number of countries and $t$ is the time period.

In order to parameterize the above equation, we have used the proposed model of Sadorsky (2011), the model examines the impact of trade openness (export + import) on energy consumption which is derived as follows:

$$
\ln E C_{i t}=\beta_{1 i}+\beta_{2 i} \ln T O_{i t}+\beta_{3 i} \ln G D P_{i t}+\beta_{4 i} \ln E P_{i t}+\epsilon_{i t}
$$

Where, cross-sections are denoted by subscript $i(i=1,2 \ldots, 4)$ and time period by a subscript $t(t=1,2, \ldots, T), \epsilon_{t}$ is the stochastic random error term. The Energy consumption data is collected in $\mathrm{kg}$ of oil as it is equivalent to per capita, real GDP per capita in constant international dollar is used to measure economic growth. Exports in US dollars plus imports in US dollar divided by population is used to measure trade openness $(T O)$.

This study used panel data over the period of 1972 to 2011 (40 years). Entire data is collected from British Petroleum Statistics of World Energy Outlook June, 2016 and World Bank for four Asian developing oil importing countries namely Pakistan, China, India and Bangladesh.

For an empirical analysis of the model (Eq 2), we used Pooled Mean Group (PMG) estimation approach of Pesaran, Shin, and Smith (1999a). Prior to estimating the model, we check the cross-sectional dependency across the countries which encourage us to test CIPS unit root and then panel cointegration.

\section{Results and Discussion}

\section{CD and CIPS Test}

To check whether cross-section dependence exists, we used CD-test proposed by Pesaran (2004). The null hypothesis of Pesaran (2004) CD test confirms the existence of cross 
sectional independence, whereas, the alternative hypothesis assumes the cross sectional dependence. The results of CD test are displayed in Table 1. It shows the rejection of null hypothesis of cross sectional independence at $10 \%$ significance level for all the variables except $\ln$ TO. Thus, we confirmed the expected existence of cross section dependence. This rejection motivated us to perform the second generation unit root test to determine the order of the series. For this, we used CIPS test proposed by Pesaran (2007), which is a prerequisite for using panel cointegration. If the variables are non-stationary at level and become stationary at first difference, then we can say that the data series is integrated of order one. In this study, the statistics of CIPS test suggests that all the studied variables are integrated at the same order I (1) (Raza, Jawaid, Afshan, \& Karim, 2015).

\section{Panel Cointegration Test}

Long-run relationship between studied variables was tested using Pedroni's panel cointegration technique. The results of Pedroni are presented in Table 1. The statistics of Panel-PP, Panel-ADF, Group-PP and Group-ADF confirm the rejection of null hypothesis at $10 \%$ significance level. Hence, it is concluded that long-run relationship exists among all the variables.

Table 1

Tests for Cross-sectional Dependence, Panel Unit Root and Panel Cointegration Results

\begin{tabular}{lcccc}
\hline Panel A: & LEC & LEP & LGDP & LTO \\
Variables & & & & \\
\hline Pesaran CD test & 14.93 & 13.91 & 14.92 & 0.869 \\
P-value & 0.000 & 0.000 & 0.000 & 0.384 \\
\hline Panel B: & & & & \\
The unit root test with cross-sectional dependence & & & & -2.334 \\
\hline CIPS test (level) & -1.493 & -2.909 & -0.711 & $-4.912^{* * *}$ \\
CIPS test (first difference) & $-5.401^{* * *}$ & $-5.191^{* * *}$ & $-5.066^{* * *}$ & \\
\hline Panel C: & & & & \\
Panel Cointegration Test & & & & \\
Panel PP-Statistics & -1.380 & $(0.0830)$ & & \\
Panel ADF-Statistics & -1.452 & $(0.0073)$ & & \\
Group-PP Statistics & -1.456 & $(0.0726)$ & & \\
Group-ADF-Statistics & -1.517 & $(0.0640)$ & & \\
***= rejection of $H_{o}$ of Pesaran (2007) CD test and also the rejection of $H_{o}$ of CIPS at $10 \%$ &
\end{tabular}

\section{Pooled Mean Group Estimates}

Pooled Mean Group (PMG) approach has the advantage to consider homogeneous long run parameters and different short run coefficients of each group. In our research, we have considered equal long run parameters because of the similar political conditions and common economic integration. But the short run coefficients are considered different across nations.

Due to the short-run heterogeneity assumption, the PMG approach is more useful and efficient than the MG estimates. According to Pesaran, Shin, and Smith (1999b), mean group estimator reduces the efficiency of the estimators. To choose the best estimator, we perform the Hausman test. This test tells the significant difference between Mean 
Group (MG) estimator and Pooled Mean Group (PMG) estimator. The null hypothesis of Hausman test is the insignificant difference between MG and PMG estimator at the 5\% significance level. If the significance value is greater than $5 \%$, we reject the null hypothesis and use PMG estimator for estimating a model. In the current study, Table 2 displays the result of Hausman test, which strongly rejects the null hypothesis because the p-value exceeds the significance level i.e. 5\%. Therefore, we reported Pooled Mean Group (PMG) estimator in our study. Table 2 also represents the results of PMG estimator, it suggests that trade openness has a great influence on the energy consumption because they both are positively related to each other. Trade openness raises the use of energy and ultimately boost the economy by raising the national output. The statistics of gross domestic product (GDP) and energy consumption (EP) reveal the positive impact of both the variables in the short and long-run. However, high energy prices reduce the energy consumption, because the both variables have inverse relationship.s

An overall empirical results confirm the positive effect of trade openness on energy consumption. It confirms that there is a positive feedback channel between trade and energy usage, which suggests that the use of new energy resources may give optimal benefits of trade. Free trade encourages industrialization that ultimately affects the economic growth. This channel directly influences the energy demand resulting in a shortage of energy supply, which hinders trade openness and reduces energy consumption.

Table 2

PMG \& MG Estimates

\begin{tabular}{lcccccccc}
\hline \multicolumn{1}{l}{ Pooled mean group and mean group estimation } \\
\multicolumn{3}{c}{ PMG Estimates } \\
& Coef. & Std. Err. & t-Ratio & p-value & Coef. & Std. Err. & t-Ratio & p-value \\
\hline $\ln \mathrm{NP}$ & -32.03 & 15.83 & -2.02 & 0.043 & -22.289 & 6.339 & -3.520 & 0.000 \\
$\operatorname{lnTO}$ & 30.62 & 18.18 & -1.68 & 0.092 & 18.62 & 15.48 & 1.200 & 0.229 \\
$\operatorname{lnGDP}$ & 0.432 & 0.054 & 8.01 & 0.000 & 0.369 & 0.035 & 10.53 & 0.000 \\
& & & & & & & & \\
\hline
\end{tabular}

Hausman test statistic: $\quad \mathrm{h}=3.17, \mathrm{p}$-value $=0.365$

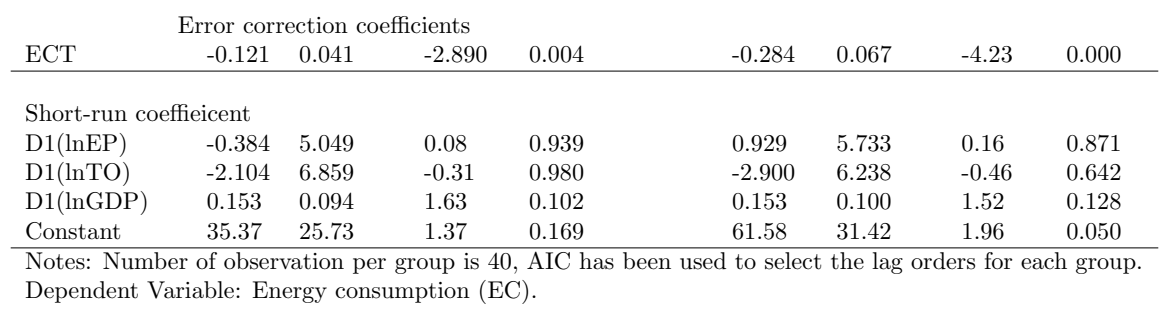

\section{Conclusion and Policy Implications}

This paper explored the impact of trade on energy consumption using the panel data of four Asian developing countries namely Pakistan, India, China and Bangladesh over the period of 1972 to 2011. By employing Pesaran (2004) CD test, it is found that the variables have cross-sectional dependency, which motivated researchers to test second order 
generation i.e. CIPS test in order to check the integration property. Pesaran (2007) CIPS test confirmed the integration of the data series at order one i.e. I (1). In addition, Pedroni panel cointegration test is used to check the long-run relationship between trade and energy consumption. Results suggested the long-run relationship of both the variables. The findings of Pooled Mean Group (PMG) method indicated that trade openness has a great and positive influence on energy consumption of the selected regions in the long run. Conversely, the relationship between energy consumption and trade become negative in the short run. Moreover, it is obtained from the findings that GDP also influences energy consumption in a positive way in both short and long-run, however; energy price is inversely related to energy consumption.

The findings of the current study have some essential implications in the considered regions i.e. Pakistan, China, India, and Bangladesh. As findings suggested the positive linkage of trade and energy consumption, therefore, the government should design energy consumption policies by considering a trade because the shortage of energy supply will highly affect the imports and exports of the country. In addition, the government ought to invest in domestic energy resources in order to prevent the country from oil crisis. The consumption of oil or any kind of energy should be done in an efficient and productive manner so that it will raise national output and subsequently the economic growth.

Furthermore, policy makers need to formulate some environment-friendly policies for energy preservation. However, the energy preservation policies will ultimately reduce trade. Thus, the state needs to advance their technology which will use energy efficiently and raise the output. The findings also suggest the positive linkage of gross domestic product and energy consumption. Therefore, a country should need to work on its own energy resources due to the fact that shortage of energy will inversely affect the national output and hence the economic growth.

This paper can be extended for the future researches by including other macroeconomic variables that directly or indirectly affect energy, trade or the output of the country. Financial development, energy crisis, energy demand, urbanization, industrialization and many other variables should also be studied in the future researches. The relationship of energy consumption and trade openness needs to be explored in some other regions specifically in developing or oil exporting countries. 


\section{References}

Al-Iriani, M. A. (2006). Energy GDP relationship revisited: An example from GCC countries using panel causality. Energy Policy, 34(17), 3342-3350.

Azam, M., Khan, A. Q., Zaman, K., \& Ahmad, M. (2015). Factors determining energy consumption: Evidence from Indonesia, Malaysia and Thailand. Renewable and Sustainable Energy Reviews, 42, 1123-1131. doi: 10.1016/j.rser.2014.10.061

Brini, R., Amara, M., \& Jemmali, H. (2017). Renewable energy consumption, international trade, oil price and economic growth inter-linkages: The case of Tunisia. Renewable and Sustainable Energy Reviews, 76, 620-627. doi: 10.1016/j.rser.2017.03.067

Chaudhry, I. S., Safdar, N., \& Farooq, F. (2012). Energy consumption and economic growth: Empirical evidence from Pakistan. Pakistan Journal of Social Sciences, 32(2), 371-382.

Gupta, E. (2008). Oil vulnerability index of oil importing countries. Energy Policy, 36(3), 1195-1211.

Halicioglu, F. (2010). An econometric analysis of the aggregate outbound tourism demand of Turkey. Tourism Economics, 16(1), 83-97.

Hye, Q. M. A., \& Riaz, S. (2008). Causality between energy consumption and economic growth: The case of Pakistan. The Lahore Journal of Economics, 13(2), 45-58.

Khan, N. A., \& Dessouky, H. E. (2009). Prospect of biodiesel in Pakistan. Renewable and Sustainable Energy Reviews, 13(6/7), 1576 -1583.

Kyophilavong, P., Shahbaz, M., Anwar, S., \& Masood, S. (2015). The energy-growth nexus in Thailand: Does trade openness boost up energy consumption? Renewable and Sustainable Energy Reviews, 46, 265-274. doi: 10.1016/j.rser.2015.02.004

Lau, E., Chye, X. H., \& Choong, C. K. (2011). Energy-Growth Causality: Asian countries revisited. International Journal of Energy Economics and Policy, 1(4), 140-149.

Lean, H. H., \& Smyth, R. (2010a). Multivariate granger causality between electricity generation, exports, prices and GDP in Malaysia. Energy, 35(9), 3640-3648.

Lean, H. H., \& Smyth, R. (2010b). On the dynamics of aggregate output, electricity consumption and exports in Malaysia: Evidence from multivariate Granger causality tests. Applied Energy, 87(6), 1963-1971.

Li, L. (2010). An empirical analysis of relationship between export and energy consumption in Shandong province. International Journal of Business and Management, 5(3), $214-216$.

Li, L. (2014). Empirical research on the relationship between China export and new energy consumption. International Journal of Energy Economics and Policy, 4(2), 229-237.

Machado, G., Schaeffer, R., \& Worrell, E. (2011). Energy and carbon embodied in the international trade of Brazil: An input-output approach. Ecological Economics, 39(3), 409-424.

Narayan, P. K., \& Smyth, R. (2009). Multivariate granger causality between electricity consumption, exports and GDP: Evidence from a panel of Middle Eastern countries. Energy Economics, 37(1), 229-236. 
Ozturk, I. (2010). A literature survey on energy-growth nexus. Energy Policy, 38(1), 340-349.

Palamalai, S., Ravindra, I. S., \& Prakasam, K. (2015). Relationship between energy consumption, CO2 emissions, economic growth and trade in India. Journal of Economic E Financial Studies, 3(2), 1-17.

Payne, J. E. (2010). Survey of the international evidence on the causal relationship between energy consumption and growth. Journal of Economic Studies, 37(1), 53-95.

Pesaran, M. H. (2004). General diagnostic tests for cross section dependence in panels. CESifo Working Paper, No. 1229.

Pesaran, M. H. (2007). A simple panel unit root test in the presence of cross-section dependence. Journal of Applied Econometrics, 22(2), 265-312.

Pesaran, M. H., Shin, Y., \& Smith, R. P. (1999a). Pooled mean group estimation of dynamic heterogeneous panels. Journal of the American Statistical Association, 94(446), 621634.

Pesaran, M. H., Shin, Y., \& Smith, R. P. (1999b). Pooled mean group estimation of dynamic heterogeneous panels. Journal of the American Statistical Association, $94(446), 621-634$.

Raza, S. A., Jawaid, S. T., Afshan, S., \& Karim, M. Z. A. (2015). Is stock market sensitive to foreign capital inflows and economic growth? Evidence from Pakistan. Journal of Chinese Economic and Foreign Trade Studies, 8(3), 142-164.

Sadorsky, P. (2011). Trade and energy consumption in the Middle East. Energy Economics, $33(5), 739-749$.

Sadorsky, P. (2012). Energy consumption, output and trade in South America. Energy Economics, 34(2), 476-488.

Shahbaz, M., \& Feridun, M. (2012). Electricity consumption and economic growth: Empirical evidence from Pakistan. Springer Science and Business Media, 46(5), 1583-1599.

Shahbaz, M., \& Lean, H. H. (2012). The dynamics of electricity consumption and economic growth: A revisit study of their causality in Pakistan. Energy, 39(1), 146-153.

Shahzad, S. J. H., Kumar, R. R., Zakaria, M., \& Hurr, M. (2017). Carbon emission, energy consumption, trade openness and financial development in Pakistan: A revisit. Renewable and Sustainable Energy Reviews, 70, 185-192. doi: 10.1016/j.rser.2016 .11 .042

Shiu, A., \& Lam, P. L. (2004). Electricity consumption and economic growth in China. Energy Policy, 32(11), 47-54.

Wasti, S. E. (2013). Pakistan Economic Survey (Survey Report). Ministry of Finance, Govt. of Pakistan.

Yang, H. Y. (2000). A note on the causal relationship between energy and GDP in Taiwan. Energy Economics, 22(3), 309-317. 